\title{
Bioactive compounds and medicinal properties of Oyster mushrooms (Pleurotus sp.)
}

\author{
Iwona Golak-Siwulska, Alina Kałużewicz*, Tomasz Spiżewski, \\ Marek Siwulski, Krzysztof Sobieralski
}

Department of Vegetable Crops Faculty of Horticulture and Landscape Architecture, Poznań University of Life Sciences Dąbrowskiego 159, Poznań, Poland

\begin{abstract}
There are about 40 species in the Pleurotus genus, including those with high economic significance, i.e. $P$. ostreatus and P. pulmonarius. The fruiting bodies of oyster mushrooms are of high nutritional and healthpromoting value. In addition, many species belonging to the Pleurotus genus have been used as sources of substances with documented medicinal properties, such as high-molecular weight bioactive compounds (polysaccharides, peptides and proteins) and low-molecular weight compounds (terpenoids, fatty acid esters and polyphenols). The bioactive substances contained in the mycelium and fruiting bodies of Pleurotus species exhibit immunostimulatory, anti-neoplastic, anti-diabetic, anti-atherosclerotic, anti-inflammatory, antibacterial and anti-oxidative properties. Their multidirectional positive influence on the human organism is the result of interaction of bioactive substances. Extracts from individual Pleurotus species can be used for the production of dietary supplements increasing the organism's immunity. They are also used for the production of cosmetics. They can be added to functional foods as probiotics, or used as natural preservatives or ingredients of special foodstuffs for patients with specific diseases.
\end{abstract}

Keywords: fruiting bodies, functional food, health-promoting activities, oyster mushrooms

\section{INTRODUCTION}

Mushrooms have been used in folk medicine all over the world since ancient times (Wasser and Weis, 1999). They have been chiefly used in traditional medicine in China and other Asian countries. Mushrooms have antineoplastic, antibacterial, antiviral, hypoglycaemic, hypocholesterolemic, anti-inflammatory and anti-oxidative properties (Guillamon et al., 2010; Wasser, 2011, 2014). Ganoderma lucidum and Lentinula edodes are the best-known species with therapeutic properties. An increasing number of studies from different centres confirm the fact that mushroom species of the Pleurotus genus exhibit multidirectional health-promoting effects (Khan and Tania, 2012; Stachowiak and Reguła, 2012; Deepalakshmi and Mirunalini, 2014; Correa et al., 2016). Many authors indicate that oyster mushrooms could be classified as functional food due to their positive effect on the human organism (Synytsya et al., 2008; Patel et al., 2012).

There are about 40 species in the Pleurotus genus (Kues and Liu, 2000). These mushrooms grow on various lignocellulosic substrates and form shellshaped fruiting bodies of high nutritional value as they are rich in proteins, vitamins and minerals.

*Corresponding author. 
At present, oyster mushrooms are the world's third most common species of cultivated mushrooms after button mushrooms and shiitake mushrooms (Fernandes et al., 2015). Poland is a leading producer of oyster mushrooms in Europe - the yearly volume of production exceeds 80,000 tonnes. P. ostreatus and $P$. pulmonarius are the most economically significant species of oyster mushrooms (dos Santos Bazanella et al., 2013).

Research on the therapeutic properties of oyster mushrooms started in the late $20^{\text {th }}$ century. First, their hypotensive properties were confirmed (Bajaj et al., 1997). Next, studies proved the anti-neoplastic properties of the mushrooms (Wang et al., 2000). Research became intensified in the early $21^{\text {st }}$ century (Cohen et al., 2002; Lavi et al., 2006; Lee et al., 2007; Li et al., 2008; Jedinak and Sliva, 2008). Studies confirmed the health-promoting and therapeutic properties of various oyster mushroom species, such as P. ostreatus (Fr.) Kumm., P. pulmonarius (Fr.) Quel., P. ostreatus f. florida Cetto, P. cornucopiae (Pers.) Roland, P. eryngii (Fr.) Kumm., P. sajor-caju (Fr.) Sing., P. citrinopileatus Sing. and P. tuberregium (Fr.) Sing.

The multidirectional health-promoting and therapeutic effects of mushrooms of the Pleurotus genus result from the presence of secondary metabolites, which have been isolated from both oyster mushroom fruiting bodies and mycelia (Morris et al., 2017). The bioactive compounds identified in Pleurotus mushrooms can be divided into those with a high and those with a low molecular weight. High-molecular weight bioactive compounds chiefly encompass polysaccharides, including $\beta$-glucans, peptides and proteins. Low-molecular weight bioactive compounds include terpenes, fatty acid esters and polyphenols (Patel and Goyal, 2012). Bioactive substances exhibit immunostimulatory, anti-neoplastic, anti-diabetic, anti-atherosclerotic, anti-inflammatory, hepatoprotective and antioxidative properties (Lindequist et al., 2005; Alam et al., 2009; Jayakumar et al., 2011; Wasser, 2014).

\section{BIOACTIVE COMPOUNDS AND THEIR ACTIVITY}

\section{Polysaccharides}

The polysaccharides contained in the mushroom cell wall include $\beta$-glucans and $\alpha$-glucans. These compounds are composed of glucopyranose molecules linked with glycosidic bonds of the type $(1 \rightarrow 3)-\beta,(1 \rightarrow 6)-\beta$ - or $(1 \rightarrow 3)-\alpha$. $\beta$-glucans are a group of polysaccharides which has been researched well. $\beta$-glucans acquired from mushrooms differ in their structure, water solubility, size of the molecule and molecular weight. They exhibit a very wide spectrum of health-promoting effects (Zhu et al., 2015; Friedman, 2016). $\beta$-glucans of higher molecular weight are more effective (Wasser, 2002). The effectiveness of $\beta$-glucans also depends on their solubility (Wasser, 2011). The physicochemical modification of polysaccharides by changing the degree of their branching or by adding substituent groups (sulphates, selenates) influences their bioactivity (Li and Shah, 2014; Witkowska, 2014).

According to Rop et al. (2009), oyster mushrooms are one of the most important sources of $\beta$-glucans. Individual oyster mushroom species differ in the concentration of total glucans, $\alpha$ - and $\beta$-glucans. According to Sari et al. (2017), total glucans

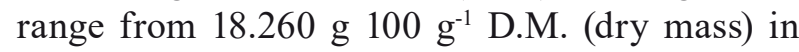

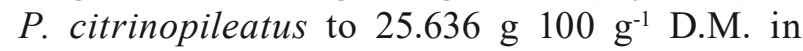
$P$. ostreatus. The concentration of $\beta$-glucans ranges

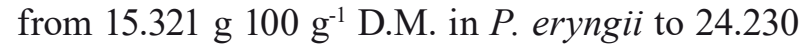
g $100 \mathrm{~g}^{-1}$ D.M. in P. ostreatus. $\beta$-glucans can also be found in the mycelium of oyster mushrooms. The total concentration of $\beta$-glucans in $P$. ostreatus fruiting bodies reaches $9 \mathrm{~g} 100 \mathrm{~g}^{-1}$ D.M. The concentration of $\beta$-glucans in the oyster mushroom

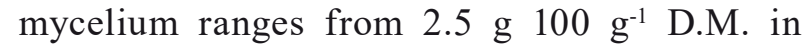

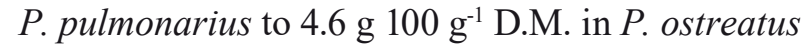
(Nitschke et al., 2011). According to Synytsya et al. (2009), the concentration of $\beta$-glucans in the stem of $P$. ostreatus fruiting bodies amounts to $32.5-50 \%$ D.M. and is higher than in the cap (27.4-39.2\% D.M.). The concentration of $\beta$-glucans in the fruiting bodies of $P$. eryngii amounts to 39.1 D.M. in the stem and 20.4\% D.M. in the cap.

Pleuran is the best-known $\beta$-glucan extracted from oyster mushrooms. It is composed of D-glucose molecules linked with bonds of the type (13)- $\beta$ - and $(1 \rightarrow 6)-\beta$-. Extraction with hot water is the most common method of acquiring pleuran from fruiting bodies. It can also be obtained from liquid cultures (Maftoun et al., 2013). The compound exhibits anti-neoplastic properties against various cells, including colorectal cancer cells HT-29 (Lavi et al., 2006), prostate cancer cells PC-3 (Gu and Sivan, 2006) and breast cancer cells MCF-7 (Martin and Brophy, 2010). In addition, it has anti-oxidative and antiviral properties (Selegean et al., 2009).

A group of polysaccharides which has not been investigated so well is that of $\alpha-(1 \rightarrow 3)$ -glucans. They can be found in the deepest layer of the mushroom cell wall. They have structural and supportive functions, and serve as a reserve 
material. $\alpha$-glucans have been found to exhibit anti-neoplastic, immunostimulatory and antioxidative properties (Wiater et al., 2012). The total concentration of $\alpha-(1 \rightarrow 3)$-glucans in the fruiting bodies of various oyster mushroom species ranges from $2.0 \%$ D.M. in P. eryngii to $4.0 \%$ D.M. in P. citrinopileatus (Sari et al., 2017). Investigations have proved that the fraction of -glucans from $P$. ostreatus fruiting bodies exhibit an antineoplastic effect against colorectal cancer cell lines (Augustin et al., 2007).

The bioactivity of $\alpha$-(1 $\rightarrow 3)$-glucans depends on their solubility, structure and concentration. The activity of linear insoluble $\alpha$-glucans can be increased by chemical modification. Investigations have proved that the derivatives produced by carboxymethylation of $\alpha-(1 \rightarrow 3)$-glucans from $P$. ostreatus exhibit high cytotoxic activity towards HeLa cell lines. The carboxymethylated $\alpha-(1 \rightarrow 3)$ -glucan isolated from $P$. citrinopileatus exhibits cytotoxic activity to cervical cancer cells but it is not toxic to normal cells (Wiater et al., 2011, 2015).

The fruiting bodies and mycelia of different oyster mushroom species have provided a wide range of polysaccharides of diversified activity. Zhang et al. (2012) isolated two fractions of polysaccharides from $P$. ostreatus and proved their strong anti-oxidative properties. Facchini et al. (2014) proved that polysaccharides extracted from the $P$. ostreatus mycelium successfully inhibited the development of neoplastic cells of Ehrlich tumour and sarcoma 180. Two substances with anti-inflammatory properties have been isolated from the $P$. sajor-caju species: $(1 \rightarrow 3)-\beta$-D-glucan and mannogalactan (Silveira et al., 2014, 2015). Cui et al. (2015) isolated the PN-S polysaccharide from $P$. nebrodensis and proved that it was capable of stimulating the activity of macrophages. Another fraction of polysaccharides (PNPA) has also been acquired from the same species. The fraction has been proved to prevent myocardial ischaemia (Yan et al., 2015). Another polysaccharide (PAP) has been acquired from $P$. abalonus. It exhibits antiproliferative properties against human colorectal cancer cells LoVo (Ren et al., 2015). Li and Shah (2014) conducted sulphatation of polysaccharides obtained from $P$. eryngii cells. The researchers proved that this fraction of polysaccharides had stronger anti-oxidative and antibacterial properties (Li and Shah, 2015). The polysaccharides isolated from the $P$. ostreatus, $P$. ostreatoroseus and $P$. florida species exhibit anti-inflammatory effects (Ghazanfari et al., 2010; Gunawardana et al., 2014;
Correa et al., 2015). Investigations have proved the anti-oxidative properties of polysaccharides obtained from P. tuber-regium (Wu et al., 2014). A $\beta$-glucan obtained from $P$. pulmonarius has been found to exhibit analgesic and anti-inflammatory effects (Baggio et al., 2012).

\section{Proteins, peptides and lectins}

Proteins, peptides and lectins are other highmolecular weight substances acquired from mushrooms of the Pleurotus genus which exhibit medicinal properties. Nebrodeolysin is a haemolytic protein isolated from $P$. nebrodensis, which induces apoptosis of neoplastic cells L929 and HeLa (Lv et al., 2009). The substance also exhibits an antiviral effect against HIV-1. A protein derived from $P$. ostreatus has a structure similar to ubiquitin and inhibits HIV-1 reverse transcriptase (Wang and $\mathrm{Ng}, 2000$ ). A protein extract obtained from $P$. ostreatus exhibited a therapeutic effect towards the colorectal cancer cell line SW 480 and monocytic leukaemia THP-1 by inducing their apoptosis (Wu et al., 2011). In addition, eryngin and pleurostrin - the proteins isolated from the $P$. eryngii and $P$. ostreatus species exhibit antifungal and antibacterial properties (Erjavec et al., 2012). The $P$. cornucopiae species has provided two oligopeptides which exhibit antihypertensive properties (Jang et al., 2011). Moreover, the mycelium and fruiting bodies of $P$. citrinopileatus contain large amounts of ergothioneine, a watersoluble amino acid, which is considered an excellent antioxidant (Lin et al., 2016).

Enzymes isolated from oyster mushrooms also exhibit health-promoting effects. Ribonuclease from $P$. djamor inhibits the proliferation of hepatic cancer and breast cancer cells (Wu et al., 2010). Research has also confirmed the antiviral effect of laccase isolated from $P$. ostreatus against the hepatitis $\mathrm{C}$ virus (El-Fakharana et al., 2010).

Lectins are another group of mushroom compounds with multidirectional health-promoting effects (Wang and $\mathrm{Ng}, 2000$; Hassan et al., 2015). Lectins include polysaccharide-protein and polysaccharide-peptide complexes. Research has proved that the polysaccharide-peptide complex from $P$. abalonus reduces the blood glucose level in mice (Chen et al., 2015). Lectins from Pleurotus citrinopileatus exhibit antineoplastic and antiviral effects (Li et al., 2008).

\section{Other compounds}

Mono- and sesquiterpenoids, ergosterol and fatty acid esters are low-molecular weight bioactive 
compounds identified in oyster mushrooms. Terpenoids exhibiting cytotoxicity towards HeLa and HepG2 cancer cells have been isolated from the $P$. cornucopiae mycelium (Wang et al., 2013). Menikpurage et al. (2009) researched the antifungal activity of different fractions isolated from $P$. cystidiosus. They found that the fraction containing ergosterol $-3 \beta, 5 \alpha, 6 \beta$-trihydoxyergosta7,22-diene was the most effective against Colletotrichum gloeosporioides fungi that cause anthracnose. Fatty acid esters in an extract from $P$. eous have been found to exhibit a strong antibacterial effect - they inhibit the growth of Gram-positive and Gram-negative bacteria (Suseem and Saral, 2013).

The fruiting bodies of mushrooms of the Pleurotus genus contain lovastatin, which belongs to the group of statins affecting the metabolism of cholesterol. These compounds inhibit LDL cholesterol oxidation and positively affect the coagulation system and fibrinolysis. They have anti-inflammatory, anticoagulation and antioxidative properties. According to Alarcon et al. (2003), the average lovastatin content in the dry matter of oyster mushrooms amounts to $0.7-2.8 \%$. The concentration of lovastatin in oyster mushroom species varies, ranging from $101 \mathrm{mg} \mathrm{kg}^{-1}$ D.M. in $P$. cystidiosus to $216 \mathrm{mg} \mathrm{kg}^{-1}$ D.M. in P. ostreatus fruiting bodies (Chen et al., 2012). Alam et al. (2009) conducted a study on animals and proved that the lovastatin contained in powdered fruiting bodies of $P$. osteratus and $P$. sajor-caju positively affected the lipid profile as well as the hepatic and renal functions. The total cholesterol and triglyceride levels in the rats' blood decreased.

Many authors have indicated that oyster mushrooms contain phenolic compounds with antioxidative effects (Palacios et al., 2011; Muszyńska et al., 2013; Piska et al., 2017). Aqueous and ethanol extracts exhibiting high anti-oxidative activity have been isolated from $P$. citrinopileatus fruiting bodies and mycelium. The highest activity has been shown by ethanol extracts from the fruiting bodies of this species due to the high total concentration of phenolic compounds (Lee et al., 2007). Investigations conducted by Jaworska et al. (2015) found that the total phenolic content in P. ostreatus fruiting bodies amounted to $708 \mathrm{mg} 100 \mathrm{~g}^{-1}$ D.M., in which the flavonoid content amounted to $170 \mathrm{mg} 100$ $\mathrm{g}^{-1}$ D.M. According to Gąsecka et al. (2016), ferulic acid and $p$-coumaric acid are the chief phenolic acids in oyster mushrooms. Their concentrations in the fruiting bodies amount to, respectively, 30.00 and $10.54 \mu \mathrm{g} \mathrm{g}^{-1}$ D.M. in P. ostreatus and to 29.00 and $13.49 \mu \mathrm{g} \mathrm{g}^{-1}$ D.M. in P. eryngii.

Medicinal activities and the bioactive substances found in some Pleurotus species are presented in Table 1.

\section{APPLICATION OF PLEUROTUS MUSHROOMS IN THE PHARMACEUTICAL, FOOD AND COSMETICS INDUSTRIES}

According to studies conducted so far, mushrooms of the Pleurotus genus exhibit numerous potentially therapeutic properties. Medicinal substances can be found in the mycelium, the fruiting bodies, and extracts from them. A therapeutic effect can be achieved by consuming fresh oyster mushroom fruiting bodies, foodstuffs containing dried oyster mushrooms or supplements with such content. The market offers a preparation based on -glucan from the fruiting bodies of $P$. ostreatus. It is used for immunotherapy when the immunity of the organism is low and there are frequent infections and allergies. Research has proved the positive influence of pleuran, which exhibits immunomodulatory properties in children with respiratory infections and allergies (Jesenak et al., 2013, 2014; Pasnik et al., 2017). Studies have also proved the positive effect of pleuran on the function of the immune system in people doing intense physical exercises (Bergendiova et al., 2011). Pleuran can be applied in antibiotic therapy and can be used in chemotherapy and radiotherapy as an adjunctive therapeutic. It also positively affects people exposed to long-lasting stress.

Oyster mushrooms can be used for the production of functional food with significant influence on human health (Wakchaure et al., 2010; CarrascoGonzalez et al., 2017; Piska et al., 2017). Pleurotus meal is used as an additive to products made from cereals, such as: breads, pastries, noodles, tortillas, etc., because it increases the protein and fibre content (Aishah and Wan Rosli, 2013). Research has proved that when the oyster mushroom additive did not exceed $10 \%$, it did not have a negative effect on the sensory evaluation of products (Adebayo-Oyetoro et al., 2010). Researchers have conducted studies on dried oyster mushrooms used as an additive to cereal products to increase their health-promoting value. Their investigations showed that dried oyster mushrooms added to maize bread and wheat bread reduced the glycaemic index of these products (Reguła and Gramza-Michałowska, 2013). The lipid profile of patients with hypercholesterolemia 
Table 1. Medicinal effects of Pleurotus mushrooms

\begin{tabular}{|c|c|c|c|}
\hline Activity & Bioactive compounds & Species & References \\
\hline \multirow[t]{4}{*}{ Anti-cancer } & $\beta$-glucans & P. ostreatus & $\begin{array}{l}\text { Jedinak et al., } 2010 \\
\text { Jedinak and Sliva, } 2008\end{array}$ \\
\hline & $\alpha$-glucan & P. ostreatus & $\begin{array}{l}\text { Lavi et al., } 2006 \\
\text { Wu et al., } 2011\end{array}$ \\
\hline & proteins & P. ostreatus & Wang and $\mathrm{Ng}, 2000$ \\
\hline & & P. nebrodensis & Lv et al., 2009 \\
\hline \multirow[t]{4}{*}{ Antitumour } & polysaccharides & P. ostreatus & Tong et al., 2009 \\
\hline & proteoglycans & P. ostreatus & Sarangi et al., 2006 \\
\hline & lectin & P. citrinopileatus & Li et al., 2008 \\
\hline & & P. ostreatus & Wang et al., 2000 \\
\hline \multirow[t]{2}{*}{ Immunomodulatory } & polysaccharides & $\begin{array}{l}\text { P. ostreatus } \\
\text { P. cornucopiae }\end{array}$ & Shamtsyan et al., 2004 \\
\hline & heteroglycan & P. ostreatus & Devi et al., 2013 \\
\hline \multirow[t]{3}{*}{ Antihypercholesterolemic } & lovastatin & P. ostreatus & Alam et al., 2009 \\
\hline & & $\begin{array}{l}\text { P. sajor-caju } \\
\text { P. florida }\end{array}$ & Khan et al., 2011 \\
\hline & ergosterol & P. ostreatus & Dissanayake et al., 2009 \\
\hline \multirow[t]{2}{*}{ Antihypertensive } & D-mannitol & P. cornucopiae & Hagiwara et al., 2005 \\
\hline & peptides & P. cornucopiae & Jang et al., 2011 \\
\hline \multirow[t]{4}{*}{ Anti-atherogenic } & $\begin{array}{l}\text { angiotensin converting } \\
\text { enzyme inhibitor peptide }\end{array}$ & P. cornucopiae & Abidin et al., 2017 \\
\hline & ergothioneine & P. eryngii & \\
\hline & chrysin & P. ostreatus & \\
\hline & lovastatin & P. ostreatus & \\
\hline \multirow[t]{4}{*}{ Antiviral } & proteins & P. ostreatus & Wang and $\mathrm{Ng}, 2000$ \\
\hline & & P. nebrodensis & Lv et al., 2009 \\
\hline & polysaccharides & P. abalonus & Wang et al., 2011 \\
\hline & lectins & P. citrinopileatus & Hassan et al., 2015 \\
\hline \multirow[t]{2}{*}{ Antibacterial } & $\beta$-glucans & P. ostreatus & $\begin{array}{l}\text { Iwalokun et al., } 2007 \\
\text { Karaman et al., } 2010 \\
\text { Mirunalini et al., } 2012\end{array}$ \\
\hline & fatty acids esters & P. eous & Suseem and Saral, 2013 \\
\hline \multirow[t]{2}{*}{ Antifungal } & ergosterol & P. cystidiosus & Menikpurage et al., 2009 \\
\hline & proteins & $\begin{array}{l}\text { P. ostreatus } \\
\text { P. eryngii }\end{array}$ & Erjavec et al., 2012 \\
\hline \multirow[t]{4}{*}{ Anti-oxidative } & phenols & P. citrinopileatus & Lee et al., 2007 \\
\hline & lectins & P. florida & Bera et al., 2011 \\
\hline & polysaccharides & P. ostreatus & $\begin{array}{l}\text { Mitra et al., } 2013 \\
\text { Jayakumar et al., } 2011\end{array}$ \\
\hline & & P. tuber-regium & Wu et al., 2014 \\
\hline \multirow[t]{3}{*}{ Hypoglycemic } & unspecified & P. ostreatus & Ravi et al., 2013 \\
\hline & $\beta$-glucans & P. sajor-caju & Kanagasabapathy et al., 2012 \\
\hline & polysaccharide-peptide & P. abalonus & Chen et al., 2015 \\
\hline \multirow[t]{3}{*}{ Anti-inflammatory } & polysaccharides & P. ostreatus & Gunawardena et al., 2014 \\
\hline & & P. ostreatoroseus & Correa et al., 2015 \\
\hline & & P. florida & Ghazanfari et al., 2010 \\
\hline \multirow[t]{2}{*}{ Anti-arthritic } & $\beta$-glucans & P. sajor-caju & Patel et al., 2012 \\
\hline & & P. ostreatus & Rovensky et al., 2011 \\
\hline Anti-atopic dermatitis & pleuran & P. ostreatus & Park et al., 2016 \\
\hline Anticataractogenic & unspecified & P. ostreatus & Isai et al., 2009 \\
\hline \multirow[t]{2}{*}{ Antinociceptive } & $\beta$-glucans & P. eous & Suseem et al., 2011 \\
\hline & & P. pulmonarius & Baggio et al., 2010, 2012 \\
\hline
\end{tabular}


improved when they consumed bread with dried oyster mushrooms rather than traditional wheat bread. The level of total cholesterol and its LDL fraction in the plasma of all the patients decreased. The people who consumed soup with dried oyster mushrooms every day for 21 days had a lower level of triglycerides and a lower total blood cholesterol level (Schneider et al., 2011).

Oyster mushrooms can also be used for the production of fermented milk beverages. Extracts from Pleurotus are a good source of prebiotics due to the high soluble fibre content (Aida et al., 2009; Synytsya et al., 2009). Research has proved that when an aqueous extract from P. ostreatus is added to yoghurt, it stimulates the growth of useful microorganisms Streptococcus thermophilus and Lactobacillus bulgaricus (Pelaes Vital et al., 2015). Studies have also proved that an extract from $P$. eous can be added to foodstuffs as a natural source of antibacterial substances (Suseem and Saral, 2013). The study by Li and Shah (2015) proved that an extract from $P$. eryngii (PEPS) could be added to fermented milk beverages as a natural preservative.

The use of oyster mushrooms in cosmetology and dermatology is another issue. Due to the presence of antioxidants, anti-ageing, anti-wrinkle, whitening and moisturising components oyster mushroom extracts can be used for the production of various cosmetics and cosmeceuticals. A line of cosmetics containing $\beta$-glucans has been produced from a few mushroom species, including $P$. nebrodensis (Hyde et al., 2010). Extracts from P. cornucopiae var. citrinopileatus applied to mice have given positive effects against atopic dermatitis (Tomiyama et al., 2008). Research has confirmed the usefulness of $P$. citrinopileatus as a source of ingredients for the production of skin care cosmetics (Meng et al., 2011). A $P$. nebrodensis extract has proven to be a very effective skin whitener and it could be used for the production of preparations against skin discoloration (Dangre et al., 2012).

Cosmetics containing mushroom extracts are very popular in Asia. They have appeared in Europe only recently. Some countries sell hand-made soap with a $P$. ostreatus extract, which regenerates the skin. Application of a pleuran-based cream as an adjunctive therapeutic to patients with atopic dermatitis has produced good results. The latest scientific reports confirm the usefulness of different oyster mushroom species as a raw material for the cosmetics industry (Taofiq et al., 2016; Wu et al., 2016; Morris et al., 2017).

\section{CONCLUSIONS}

According to the current state of knowledge, Pleurotus mushrooms are a good source of bioactive substances. Although in recent years the number of studies on the health-promoting effects of Pleurotus mushrooms has increased rapidly, most of them have involved in vitro or in vivo experiments on animals. So far, there have been relatively few clinical trials on humans. At the same time, it is necessary to stress the fact that not all mechanisms of action of bioactive substances in oyster mushrooms have been fully investigated. At present, stateof-the-art techniques are being applied in intense research to extract new metabolites from oyster mushrooms. It will be necessary to verify their pharmacological effects in vitro and in clinical trials. The identification of the synergic effect of these substances in the human organism would give a possibility to take full advantage of the healthpromoting and therapeutic potential of oyster mushrooms.

\section{AUTHOR CONTRIBUTIONS}

I.G.S - reviewed the relevant literature and wrote the manuscript; A.K - co-wrote the manuscript and prepared it for submission; M.S. - revised the text; T.S. and K.S. - contributed to such aspects of this manuscript as development of the idea, review of available literature and writing. All the authors are equally responsible for the content.

\section{CONFLICT OF INTEREST}

Authors declare no conflict of interest.

\section{REFERENCES}

Abidin M.H.Z., Abdullah N., Abidin N.Z, 2017. Therapeutic properties of Pleurotus species (Oyster mushrooms) for Atherosclerosis: a review. Int. J. Food Prop. 20, 1251-1261.

Adebayo-Oyetoro A., Olatidoye O., Ogundipe O., Balagun I., Aro F., 2010. Quality characteristics of cookies produced from composite flours of wheat and mushrooms. J. Sci. Multidiscip. Res. 2, 25-31.

Aida F.M.N.A., Shuhaimi M., Yazid M., MaAruf A.G., 2009. Mushrooms as a potential source of prebiotics, a review. Trends Food Sci. Technol. 20, 567-575.

Aishah M.S., Wan Rosli W.I., 2013. The effect of addition of oyster mushroom (Pleurotus sajor-caju) on nutrient composition and sensory acceptation of selected wheat-and rice-based products. Intern. Food Res. J. 20(1), 183-188.

Alam N., Amin R., Khan A., Ara I., Shim M.J., Lee M.W., 2009. Comparative effects of oyster mushroom 
on lipid profile, liver and kidney function in hypercholesterolemic rats. Mycobiology 37, 37-42.

Alarcon J., Aguila S., Arancibia-Avila P., Fuentes O., Zamorano-Ponce E., Hernandez M., 2003. Production and purification of statins from Pleurotus ostreatus (Basidiomycetes) strains. Z. Naturforsch. C 58(1-2), 62-64.

Augustín J., Jaworska G., Dandár A., Cejpek K., 2007. Boczniak ostrygowaty (Pleurotus ostreatus) jako źródło $\beta$-D-glukanów. Żywn. Nauka. Technol. Jakość 6(55), 170-176.

Baggio C.H., Freitas C.S. Martins D.F., Mazzardo L., Smiderle F.R., Sassaki G.L., et al., 2010. Antinociceptive effects of $(1 \rightarrow 3),(1 \rightarrow 6)$-linked -glucan isolated from Pleurotus pulmonarius in models of acute and neuropathic pain in mice: evidence for a role for glutamatergic receptors and cytokine pathways. J. Pain 11, 965-971.

Baggio C.H., Freitas C.S., Marcon R., Werner M.F.P., Rae G.A., Smiderle F.R., et Al., 2012. Antinociception of $\beta$-D-glucan from Pleurotus pulmonarius is possibly related to protein kinase $\mathrm{C}$ inhibition. Int. J. Biol. Macromol. 50, 872-877.

Bajaj M., Vadhera S., Brar A., Soni G., 1997. Role of oyster mushroom (Pleurotus florida) as hypocholesterolemic/antiatherogenic agent. Indian J. Exp. Biol. 35(10), 1070-1075.

dos Santos Bazanella G.C., De Souza D.F., Castoldi R., Oliveira R.F., Bracht A., Peralta R.M., 2013. Production of laccase and manganese peroxidase by Pleurotus pulmonarius in solid-state cultures and application in dye decolorization. Folia Microbiol. 58, 641-647.

Bera A.K., Rana T., Das S., Bhattacharya D., Pan D., Bandyopadhyay S., ET AL., 2011. Mitigation of arsenic-mediated renal oxidative stress in rat by Pleurotus florida lectin. Hum. Exp. Toxicol. 30(8), 940-951.

Bergendiova K., Tibenska E., Majtan J., 2011. Pleuran ( $\beta$-glucan from Pleurotus ostreatus) supplementation, cellular immune response and respiratory tract infections in athletes. Eur. J. Appl. Physiol 111, 20332040.

Carrasco-Gonzalez J.A., Serna-Saldivar S.O., GutierreZ-Uribe J.A., 2017. Nutritional composition and nutraceutical properties of the Pleurotus fruiting bodies: Potential use as food ingredient. J. Food Comp. Anal. 58, 69-81.

Chen R.-R., Liu Z.-K., LiU F., NG T.B., 2015. Antihyperglycemic mechanism of an aceteoside polymer from rose flowers and a polysaccharideprotein complex from abalone mushroom. Nat. Prod. Res. 29, 558-561.

Chen S.-Y., Ho K.-J., Hsieh Y.-J., Wang L.-T., Mau J.L., 2012. Contents of lovastatin, $\gamma$-aminobutyric acid and ergothioneine in mushroom fruiting bodies and mycelia. LWT - Food Sci. Technol. 47(2), 274-278.
Cohen R., Persky L., Hadar Y., 2002. Biotechnological applications and potential of wood-grading mushrooms of the genus Pleurotus. Appl. Microbiol. Biotechnol. 58, 582-594.

Correa R.G.G., Brugnari T., Bracht A., Peralta R.M., Ferreira I.C.F.R., 2016. Biotechnological, nutritional and therapeutic uses of Pleurotus spp. (Oyster mushrooms) related with its chemical composition: A review on the past decade findings. Trends Food Sci. Technol. 50, 103-117.

Cui H.-Y., Wang C.-L., Wang Y.-R., Li. Z.-J., Zhang Y.N., 2015. The polysaccharide isolated from Pleurotus nebrodensis (PN-S) shows immune-stimulating activity in RAW264.7 macrophages. Chin. J. Nat. Med. 13, 355-360.

Dangre D.M., Dafne L.P., Bhagat R.P., ChandekaR C.J., 2012. Effect of Pleurotus nebrodensis extract on melanin synthesis: a natural alternative for cosmetics. Int. J. Med. Arom. Plants 2(4), 579-588.

Deepalakshmi K., Mirunalini S., 2014. Pleurotus ostreatus: an oyster mushroom with nutritional and medicinal properties. J. Biochem. Tech. 5(2), 718-726.

Devi K.S.P., Roy B., Patra P., Sahoo B., Islam S.S., Maiti T.K., 2013. Characterization and lectin microarray of an immunomodulatory heteroglycan from Pleurotus osteratus mycelia. Carbohydr. Polym. 94(2), 857-865.

Dissanayake D.P., Abeytunga D.T.U., Vasudewa N.S., RATNASOORIYA W.D., 2009. Inhibition of lipid peroxidation by extracts of Pleurotus ostreatus. Pharmacogn. Mag. 5(19), 266-271.

El-Fakharany E.M., Haroun B.M., NG T.B., Redwan E.R., 2010. Oyster mushroom laccase inhibits hepatitis $\mathrm{C}$ virus entry into peripheral blood cells and hepatoma cells. Protein Pept. Lett. 17, 1031-1039.

Erjavec J., Kos J., Ravnikar M., Dreo T., Sabotic J., 2012. Proteins of higher fungi - from forest to application. Trends Biotechnol. 30, 259-273.

Facchini J.M., Alves E.P., Aguilera C., Gern R.M.M., Silveira M.L.L., Wisbeck E., ET AL., 2014. Antitumor activity of Pleurotus ostreatus polysaccharide fractions on Ehrlich tumor and Sarcoma 180. Int. J. Biol. Macromol. 68, 72-77.

Fernandes A., Barros L., Martins A., Herbert P., FERREIRA I.C.F.R., 2015. Nutritional characterization of Pleurotus ostreatus (Jacq. ex Fr.) P. Kumm. produced using paper scraps as substrate. Food Chem. 169, 396-400.

Friedman M., 2016. Mushroom polysaccharides: chemistry and antiobesity, antidiabetes, anticancer, and antibiotic properties in cells, rodents, and humans. Foods 5(4): 80, doi:10.3390/foods5040080.

GąSecka M., MleczeK M., Siwulski M., NiedZielski P., 2016. Phenolic composition and antioxidant properties of Pleurotus ostreatus and Pleurotus eryngii enriched with selenium and zinc. Eur. Food Res. Technol. 242, 723-732. 
GhazANFARi T., YARAEe R., FARAhneJad Z., RAhMati B., HAKimZADEH H., 2010. Macrophages activation and nitric oxide alterations in mice treated with Pleurotus florida. Immunopharmacol. Immunotoxicol. 31, 4750.

Correa R.C.G., De Souza A.H.P., Calhelha R.C., Barros L., Glamoclija J., Sokovic M., et AL., 2015. Bioactive formulations prepared from fruiting bodies and submerged culture mycelia of the Brazilian edible mushroom Pleurotus ostreatoroseus Singer. Food Funct. 6, 2155-2164.

Gu Y.-H., Sivam G., 2006. Cytotoxic effect of oyster mushroom Pleurotus ostreatus on human androgenindependent prostate cancer PC-3 cells. J. Med. Food 9, 196-204.

Guillamon E., Garcia-Lafuente A., Lozano M., D’Arrigo M., Rostagno M.A., Villares A., et Al., 2010. Edible mushrooms: role in the prevention of cardiovascular diseases. Fitoterapia 81, 715-723.

Gunawardena D., Bennett L., Shanmugan K., King K., Wiliams R., Zabarasa D., eT al., 2014. Antiinflammatory effects of five commercially available mushroom species determined in lipopolysaccharide and interferon- $\gamma$ activated murine macrophages. Food Chem. 148, 92-96.

Hagiwara S.-Y., Takahashi M., Shen Y., Kaihou S., Tomiyama T., Yazawa M. et Al., 2005. A phytochemical in the edible tamogi-take mushroom (Pleurotus cornucopiae), D-mannitol, inhibits ACE activity and lowers the blood pressure of spontaneously hypertensive rats. Biosci. Biotechnol. Biochem. 69, 1603-605.

Hassan M., Rouf R., Tiralongo E., May T., Tiralongo J., 2015. Mushroom lectins: specificity, structure and bioactivity relevant to human disease. Int. J. Mol. Sci. 16, 7802-7838.

Hyde K.D., BahKali A.H., Moslem M.A., 2010. Fungi - an unusual source for cosmetics. Fungal Divers. 43, $1-9$.

Isai M., Elanchezhian R., Sakthivel M., Chinnakkaruppan A., Rajamohan M., Jesudasan C.N., ET AL., 2009. Anticataractogenic effect of an extract of the oyster mushroom, Pleurotus ostreatus, in an experimental animal model. Curr. Eye Res. 34, 264-273.

Iwalokun B.A., Usen U.A., Otunba A.A., Olukoya D.K., 2007. Comparative phytochemical evaluation, antimicrobial and antioxidant properties of Pleurotus ostreatus. Afr. J. Biotechnol. 6(15), 1732-1739.

JANG J.-H., JeONG S.-C., KIM J.-H., LeE Y.-H., Ju Y.C., LEE J.-S., 2011. Characterization of a new antihypertensive angiotensin 1-converting enzyme inhibitory peptide from Pleurotus cornucopiae. Food Chem. 127, 412-418.

Jaworska G., Pogoń K., Bernaś E., Duda-Chodak A., 2015. Nutraceuticals and antioxidant activity of prepared for consumption commercial mushrooms
Agaricus bisporus and Pleurotus ostreatus. J. Food Qual. 38(2), 111-122.

Jayakumar T., Thomas P.A., Sheu J.R., Geraldine P., 2011. In-vitro and in-vivo antioxidant effects of the oyster mushrooms P. ostreatus. Food Res. Int. 44, 851-861.

Jedinak A., Dudhgaonkar S., Jiang J., Sandusky G., Sliva D., 2010. Pleurotus ostreatus inhibits colitisrelated colon carcinogenesis in mice. Int. J. Mol. Med. 26, 643-650.

Jedinak A., Sliva D., 2008. Pleurotus ostreatus inhibits proliferation of human breast and colon cancer cells through p53-dependent pathway. Int. J. Oncol. 33, 1307-1313.

Jesenak M., Hrubisko M., Majtan J., Rennerova Z., BANOvCIN P., 2014. Anti-allergic effect of pleuran ( $\beta$-glucan from Pleurotus ostreatus) in children with recurrent respiratory tract infections. Phytother. Res. 28, 471-474.

Jesenak M., Majtan J., Rennerova Z., Kyselovic J., BANOVCIN P., HrubisKo M., 2013. Immunomodulatory effect of pleuran ( $\beta$-glucan from Pleurotus ostreatus) in children with recurrent respiratory tract infections. Int. Immunopharmacol. 15, 395-399.

Kanagasabapathy G., Kuppusamy U.R., Malek S.N.A., Abdulla M.A., Chua K.-H., Sabaratnam V., 2012. Glucan-rich polysaccharides from Pleurotus sajorcaju (Fr.) Singer prevents glucose intolerance, insulin resistance and inflammation in $\mathrm{C} 57 \mathrm{BL} / 6 \mathrm{~J}$ mice fed a high-fat diet. BMC Complement. Altern. Med. 12: 261, doi:10.1186/1472-6882-12-261.

Karaman M., Jovin E., Malbasa R., Matavuly M., Popovic M., 2010. Medicinal and edible lignicolous fungi as natural source of antioxidative and antibacterial agents. Phytother. Res. 24, 1473-1481.

Khan M.A., Rahman M.M., Tania M., Uddin M.N., Ahmed S., 2011. Pleurotus sajor-caju and Pleurotus florida mushrooms improve some extent of the antioxidant systems in the liver of hypercholesterolemic rats. Open Nutraceuticals J. 4, 20-24.

Khan M.A., TAnia M., 2012. Nutritional and medicinal importance of Pleurotus mushrooms: an overview. Food Rev. Int. 28, 313-329.

Kues U., LiU Y., 2000. Fruiting body production in basidiomycetes. Appl. Microbiol. Biotechnol. 54, 141-152.

Lavi I., Friesem D., Geresh S., Hadar Y., Schwartz B., 2006. An aqueous polysaccharide extract from the edible mushroom Pleurotus ostreatus induces antiproliferative and pro-apoptotic effect on HT-29 colon cancer cells. Cancer Lett. 244, 61-70.

Lee Y.-L., Huang G.-W., Liang Z.-C., Mau J.-L., 2007. Antioxidant properties of three extracts from Pleurotus citrinopileatus. LWT - Food Sci. Technol. 40, 823-833.

Li S., Sнah N.P., 2014. Antioxidant and antibacterial activities of sulphated polysaccharides from Pleurotus 
eryngii and Streptococcus thermophilus ASCC 1275. Food Chem. 165, 262-270.

Li S., Sнah N.P., 2015. Effect of Pleurotus eryngii polysaccharides on bacterial growth, texture properties, proteolityc capacity, and angiotensin-Iconverting enzyme-inhibitory activities of fermented milk. J. Dairy Sci. 98, 2949-2961.

Li Y.R., Liu Q.H., Wang H.X., NG T.B., 2008. A novel lectin with potent antitumor, mitogenic and HIV1 reverse transcriptase inhibitor activities from the edible mushroom Pleurotus citrinopileatus. Biochim. Biophys. Acta Gen. Sub. 1780, 51-57.

Lin S.-Y., Chien S.-C., Wang S.-Y., MaU J.-L., 2016. Nonvolatile taste components and antioxidant properties of fruiting body and mycelium with high ergothioneine content from the culinary-medicinal golden oyster mushroom Pleurotus citrinopileatus (Agaricomycetes). Int. J. Med. Mushr. 18(8), 689-698.

Lindequist U., Niedermeyer T.H.J., Julich W.-D., 2005. The pharmacological potentials of mushrooms. Evid-Based Complement. Alternat. Med. 2, 285-299.

Lv H., Kong Y., YaO Q., Zhang B., Leng F.-W., Bian H.-J., ET AL., 2009. Nebrodeolysin, a novel hemolytic protein from mushroom Pleurotus nebrodensis with apoptosis-inducing and anti-HIV-1 effects. Phytomed. 16, 198-205.

Maftoun P., Malek R., Abdel-Sadek M., Aziz R., El Enshasy H., 2013. Bioprocess for semi-industrial production of immunomodulator polysaccharide Pleuran by Pleurotus ostreatus in submerged culture. J. Sci. Industrial Res. 72, 655-662.

Martin K.R., Brophy S.K., 2010. Commonly consumed and specialty dietary mushrooms reduce cellular proliferation in MCF-7 human breast cancer cells. Exp. Biol. Med. 235, 1306-1314.

Meng T.-X., Furuta S., Fukamizu S., Yamamoto R., Ishikawa H., Arung E.T., ET AL., 2011. Evaluation of biological activities of extracts from the fruiting body of Pleurotus citrinopileatus for skin cosmetics. J. Wood Sci. 57, 452-458.

Menikpurage I.P., Abeytunga D.T.U., JaCobsen N.E., Wijesundara R.L.C., 2009. An oxidize ergosterol from Pleurotus cystidiosus active against anthracnose causing Colletotrichum gloeosporioides. Mycopathologia 167, 155-162.

Mirunalini S., Arulmozhi V., Deepalakshmi K., KrishnaVENi M., 2012. Intracellular biosynthesis and antibacterial activity of silver nanoparticles using edible mushrooms. Not. Sic. Biol. 4 (4), 55-61.

Mitra P., Khatua S., Acharya K., 2013. Free radical scavenging and NOS activation properties of water soluble crude polysaccharides from Pleurotus ostreatus. Asian J. Pharm. Clin. Res. 6 (3), 67-70.

Morris H.J., Beltran Y., Llaurado G., Batista P.L., Perraud-Gaime I., Garcia N., ET AL., 2017. Mycelia from Pleurotus sp. (oyster mushroom): a new wave of antimicrobials, anticancer and antioxidant bio- ingredients. Int. J. Phytocosm. Nat. Ingred. 2, 14, doi: 10.15171/ijpni.2017.14.

Muszyńska B., SuŁkowska-Ziaja K., Ekiert H., 2013. Phenolic acids in selected edible basidiomycota species: Armillaria mellea, Boletus badius, Boletus edulis, Cantharellus cibarius, Lactarius deliciosus and Pleurotus ostreatus. Acta Sci. Pol., Hortorum Cultus 12, 107-116.

Nitschke J., Modick H., Busch E., von Rekowski R.W., Altenbach H.-J., Mölleken H., 2011. A new colorimetric method to quantify $\beta$-1,3-1,6-glucans in comparison with total $\beta$-1,3-glucans in edible mushrooms. Food Chem. 127(2), 791-796.

Palacios I., Lozano M., Moro C., D’Arrigo M., Rostagno M.A., Martínez J.A., et AL., 2011. Antioxidant properties of phenolic compounds occurring in edible mushrooms. Food Chem. 128, 674-678.

Park K.H., Lee E.S., Jin Y.I., Myung K.S., Park H.W., PARK C.G. ET AL. 2016. Inhibitory effect of Panax ginseng and Pleurotus osteratus complex on expression of cytokine genes induced by extract of Dermatophagoides pteronissinus in human monocytic THP-1 and EoL-1 cells. J. Mushroom Sci. Prod. 14 (4), 155-161.

Pasnik J., Ślemp A., Cywinska-Bernas A., Zeman K., JesenaK M., 2017. Preventive effect of pleuran ( $\beta$-glucan from Pleurotus ostreatus) in children with recurrent respiratory tract infections-open-label prospective study. Curr. Pediatr. Res. 21(1), 99-104.

Patel S., Goyal A., 2012. Recent developments in mushroom as anti-cancer therapeutics: a review. 3 Biotech.. 2, 1-15.

Patel Y., Naraian R., Singh V.K., 2012. Medicinal properties of Pleurotus species (Oyster mushrooms): a review. World J. Fungal Plant Biol. 3(1), 1-12.

Pelaes Vital A.C., Goto P.A.., Hanai L.N., Gomesda-Costa S.M., de Abreu Filho B.A., NaKamura C.V., ET AL., 2015. Microbiological, functional and rheological properties of low fat yogurt supplemented with Pleurotus ostreatus aqueous extract. LWT - Food Sci. Technol. 64, 1028-1035.

Piska K., SuŁkowksa-Ziaja K., Muszyńska B., 2017. Edible mushroom Pleurotus ostreatus (oyster mushroom) - its dietary significance and biological activity. Acta Sci. Pol., Hortorum Cultus 16(1), 151161.

Ravi B., Renitta R.E., Prabha M.L., Issac R., Naidu S., 2013. Evaluation of antidiabetic potential of oyster mushroom (Pleurotus ostreatus) in alloxan-induced diabetic mice. Immunopharmacol. Immunotoxicol. 35(1), 101-109.

ReguŁa J., Gramza-MichaŁOWSKa A., 2013. Nutritional value and glycemic index of cereal products with dried oyster mushroom (Pleurotus ostreatus) added. Żywn. Nauka Technol. Jakość 5, 119-128.

Ren D., Jiao Y., Yang X., Yuan L., Guo J., Zhao Y., 2015. Antioxidant and antitumor effects of 
polysaccharides from the fungus Pleurotus abalonus. Chem.-Biol. Interact. 237, 166-174.

Rop O., Mlcek J., Jurikova T., 2009. Beta-glucans in higher fungi and their health effects. Nutr. Rev. 67, 624-631.

Rovensky J., Stancikova M., Svik K., Bauerova K., JuRCOVICOVA J., 2011. The effects of $\beta$-glucan isolated from Pleurotus ostreatus on methotrexate treatment in rats with adjuvant arthritis. Rheumatol. Int. 31: 507511.

Sarangi I., Ghosh D., Bhutia S.K., Mallick S.K., Maiti T.K., 2006. Anti-tumor and immunomodulating effects of Pleurotus ostreatus mycelia-derived proteoglycans. Int. Immunopharmacol. 6, 1287-1297.

Sari M., Prange A., Lelley J.I., Hambitzer R., 2017. Screening of beta-glucan contents in commercially cultivated and wild growing mushrooms. Food Chem. 216, 45-51.

Schneider I., Kressel G., Meyer A., Krings U., Berger R. G., HAHN A., 2011. Lipid lowering effects of oyster mushroom (Pleurotus ostreatus) in humans. J. Funct. Foods 3, 17-24.

Selegean M., Putz M.V., Rugea T., 2009. Effect of the polysaccharide extract from the edible mushroom Pleurotus ostreatus against infectious bursal disease virus. Int. J. Mol. Sci. 10: 3616-3634.

Shamtsyan M.M., Konusova V.G., Goloshchev A.M., Maksimowva Y.O., Panchenko A.V., PetrishcheV N.N., ET AL. 2004. Immunomodulating and antitumor effects of basidiomycetes Pleurotus ostreatus (Jacq.: Fr.) P. Kumm. and P. cornucopiae (Pau. Ex Pers.) Rollan. J. Biol. Phys. Chem. 4 (3), 157-161.

Silveira M.L.L., Smiderle F.R., Agostini F., Pereira E.M., Bonatti-Chaves M., WisBeck E., ET AL., 2015. Exopolysaccharide produced by Pleurotus sajor-caju: its chemical structure and anti-inflammatory activity. Int. J. Biol. Macromol. 75, 90-96.

Silveira M.L.L., Smiderle F.R., Moraes C.P., Borato D.G., Baggio C.H., Ruthes A.C., 2014. Structural characterization and anti-inflammatory activity of a linear $\beta$-D-glucan isolated from Pleurotus sajorcaju. Carbohydr. Polym. 113, 588-596.

Stachowiak B., Regula J., 2012. Health-promoting potential of edible macromycetes under special consideration of polysaccharides: a review. Eur. Foods Res. Technol. 234, 369-380.

Suseem S.R., Saral A.M., Reddy P.N., Marslin G., 2011. Evaluation of analgesic activity of ethyl acetate, methanol and aqueous extracts of Pleurotus eous mushroom. Asian Pac. J. Trop. Med. 4, 117-120.

Suseem S.R., Saral A.M., 2013. Analysis on essential fatty acid esters of mushrooms Pleurotus eous and its antibacterial activity. Asian J. Pharmaceut. Clin. Res. 6, 188-191.

Synytsya A., Mickova K., Jablonsky I., Slukova M., Copikova J., 2008. Mushrooms of genus Pleurotus as a source of dietary fibres and glucans for food supplements. Czech J. Food Sci. 26(6), 441-446.
Synytsya A., Mickova K., Synytsya A., Jablonsky I., SpevaceK J., Erban V. et AL., 2009. Glucans from fruit bodies of cultivated mushroom Pleurotus ostreatus and Pleurotus eryngii: Structure and potential prebiotic activity. Carbohyd. Polym. 76, 548-556.

Taofiq O., Gonzalez-Paramas A.M., Martins A., Barreiro M.F., Ferreira I.C.F.R., 2016. Mushroom extracts and compounds in cosmetics, cosmeceuticals and nutricosmetics - a review. Indust. Crops Prod. 90, 38-48.

Tomiyama T., Kaihou S., Ishida M., Nishikawa H., Yamazaki N., Tsuji K. ET AL., 2008. The water retention effects and action for atopic dermatitis-like symptoms of ethyl alcohol extract (from tamogitake [Pleurotus cornucopiae var. citrinopileatus] mushroom) on animal model of atopic dermatitis. J. Japan Soc. Nutr. Food. Sci. 61, 21-26.

Tong H., Xia F., Feng K., Sun G., Gao X., Sun L. et AL., 2009. Structural characterization and in vitro antitumor activity of a novel polysaccharide isolated from the fruiting bodies of Pleurotus ostreatus. Bioresour. Technol. 100, 1682-1686.

Wakchaure G.C., Shirur M., Manikandan K., Rana L., 2010. Development and evaluation of oyster mushroom value added products. Mushroom Res. 19(1), 40-44.

Wang C.R., Ng T.B., Li L., Fang J.C., JiAng Y., WeN T.Y. ET AL., 2011. Isolation of a polysaccharide with antiproliferative, hypoglycemic, antioxidant and HIV1 reverse transcriptase inhibitory activities from the fruiting bodies of the abalone mushroom Pleurotus abalonus. J. Pharm. Pharmacol. 63, 825-832.

Wang H., GaO J., NG T.B., 2000. A new lactin with highly potent antihepatoma and antisarcoma activities from the oyster mushroom Pleurotus ostreatus. Biochem. Biophys. Res. Commun. 275, 810-816.

WANG H.X., NG T.B., 2000. Isolation of a novel ubiquitinlike protein from Pleurotus ostreatus mushroom with ant-human immunodeficiency virus, translationinhibitory and ribonuclease activities. Biochem. Biophys. Res. Commun. 276, 587-593.

Wang S., BaO L., Zhao F., WANG Q., Li S., Ren J., ET AL., 2013. Isolation, identification and bioactivity of monoterpenoids and sesquiterpenoids from the mycelia of edible mushroom Pleurotus cornucopiae. J. Agric. Food Chem. 61, 5122-5129.

WASSER S.P., 2002. Medicinal mushrooms as a source of antitumor and immunomodulating polysaccharides. Appl. Microbiol. Biotechnol. 60, 258-274.

WAsser S.P., 2011. Current finding, future trends, and unsolved problems in studies of medicinal mushrooms. Appl. Microbiol. Biotechnol. 89, 13231332.

WASSER S.P., 2014. Medicinal mushroom science: current perspectives, advances, evidences and challenges. Biomed. J. 37, 345-356. 
WASSER S.P., WeIs A.L., 1999. Medicinal properties of substances occurring in higher Basidiomycetes mashrooms: current perspectives (Review). Int. J. Med. Mushroom 1, 31-62.

Wiater A., Paduch R., Choma A., Pleszczyńska M., Siwulski M., Dominik J. ET AL., 2012. Biological study on carboxymethylated $(1 \rightarrow 3)$ - $\alpha$-D-glucans from fruiting bodies of Ganoderma lucidum. Int. J. Biol. Macromol. 51, 1014-1023.

Wiater A., Paduch R., Pleszczyńska M., Próchniak K., Choma A., Kandefer-Szerszeń M., eT AL., 2011. $\alpha-(1 \rightarrow 3)-D-G l u c a n s$ from fruiting bodies of selected macromycetes fungi and the biological activity of their carboxymethylated products. Biotechnol. Lett. 33, 787-795.

Wiater A., Paduch R., Próchniak K., Pleszczyńska M., Siwulski M., Bialas W., ET AL., 2015. Assessing biological activity of carboxymethylated derivatives of $\alpha$ - $(1 \rightarrow 3)$-glucans isolated from fruiting bodies of cultivated Pleurotus species. Żywn. Nauka Technol. Jakość 1(98), 193-206.

WitKowska A.M., 2014. Selenium-fortified mushrooms - candidates for nutraceuticals? Austin Ther. 1, 1-4.

Wu G.-H., Hu T., Li Z.-Y., HuANG Z.-L., JiAnG J.-G., 2014. In vitro antioxidant activities of the polysaccharides from Pleurotus tuber-regium (Fr.) Sing. Food Chem. 148, 351-356.
Wu J.-Y., Chen C.-H., Chang W.-H., Chung K.-T., LiU Y.-W., Lu F.-J., ET AL., 2011. Anti-cancer effects of protein extracts from Calvatia lilacina, Pleurotus ostreatus and Volvariella volvacea. Evid.-Based Complement. Alternat. Med., doi:10.1093/ecam/ neq057.

Wu X., Zheng S., Cui L., Wang H., NG T.B., 2010. Isolation and characterization of a novel ribonuclease from the pink oyster mushroom Pleurotus djamor. J. Gen. Appl. Microbiol. 56, 231-239.

Wu Y., Choi M.-H., Li J., YANG H., Shin H.-J., 2016. Mushroom cosmetics: the present and future. Cosmetics 3(3), 22, doi:10.3390/cosmetics3030022.

YAn B., Jing L., WANG J., 2015. A polysaccharide (PNPA) from Pleurotus nebrodensis offers cardiac protection against ischemia-reperfusion injury in rats. Carbohyd. Polym. 133, 1-7.

Zhang Y., Dai L., Kong X., Chen L., 2012. Characterization and in vitro antioxidant activities of polysaccharides from Pleurotus ostreatus. Int. J. Biol. Macromol. 51(3), 259-265.

Zhu F., Du B., Bian Z., Xu B., 2015. Beta-glucans from edible and medicinal mushrooms: characteristics, physicochemical and biological activities. J. Food Comp. Anal. 41, 165-173.

Received November 4, 2017; accepted February 19, 2018 